\title{
Artificial sweeteners elicit oxidative stress in rat brain and development of microcytic anemia: Promising protective effects of vitamin C
}

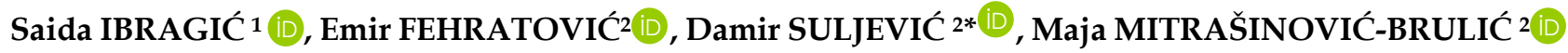 \\ 1 Department of Chemistry, Faculty of Science, University of Sarajevo, Sarajevo, Bosnia and Herzegovina. \\ 2 Department of Biology, Faculty of Science, University of Sarajevo, Sarajevo, Bosnia and Herzegovina \\ * Corresponding Author. E-mail: suljevic.damir@gmail.com (D.S.); Tel. +387-033-72 3776.
}

Received: 26 November 2020 / Revised: 03 February 2021 / Accepted: 09 February 2021

\begin{abstract}
The aim of this study was to evaluate the effects of sodium cyclamate and saccharine combination on the overall hematological parameters and brain catalase activity in Wistar rats. During a period of 8 weeks, the animals were given the artificial sweeteners in a low $(\mathrm{L} ; 15,4 \mathrm{mg} / \mathrm{mL})$ and high dose $(\mathrm{H} ; 22 \mathrm{mg} / \mathrm{mL})$. Additionally, to determine whether vitamin $\mathrm{C}$ can attenuate the changes induced by high doses, it was administered to a third group of animals $(\mathrm{H}+$ vit $\mathrm{C} ; 22 \mathrm{mg} / \mathrm{mL}+25 \mathrm{mg} / \mathrm{mL})$. Decreased hematocrit and hemoglobin values, low erythrocyte count and mean cell volume in the groups treated with the artificial sweeteners were the main hematological changes causing microcytic anemia. Catalase activity in brain tissue decreased with the increase of the sweeteners dose, which clearly indicates the induction of oxidative stress. Further on, catalase was significantly increased in the $\mathrm{H}+$ vit $\mathrm{C}$ group compared to the $\mathrm{H}$ group but there was no significant difference compared to controls. Collectively, these results suggest that sodium cyclamate and saccharine induced considerable alterations in the hematology, an increased consumption of catalase and a high efficiency of vitamin $\mathrm{C}$ to ameliorate the oxidative stress.
\end{abstract}

KEYWORDS: Mamamlian model; catalase activity; blood; cyclamates; saccharine; ascorbic acid.

\section{INTRODUCTION}

According to the World Health Organization, the amount of added sugars, i.e. sweeteners, should be lowered to $5 \%$ relative to the daily caloric intake [1]. Saccharine is the oldest artificial sweetener and the initial concerns about its carcinogenicity have been disregarded by extensive research on human populations where no association between saccharine and cancer was found [2]. Cyclamate itself shows very low toxicity but it may be metabolized by the human gut bacteria to cyclohexylamine which shows greater toxicity [3]. However, recent studies have provided new data on the extent to which individuals recognized as converters metabolize cyclamate to cyclohexylamine during long-term consumption [4].

Cyclamate is often blended with saccharine in order to improve palatability [5]. The LD50 (median lethal dose) values for sodium cyclamate, sodium saccharine and their 10: 1 combination $(15.25 \pm 1.15 \mathrm{mg} / \mathrm{kg}$, p.o.; $14.2 \pm 1.3 \mathrm{mg} / \mathrm{kg}$ p.o.; and $21.5 \pm 1.8 \mathrm{mg} / \mathrm{kg}$, p.o. respectively) can be found in one of the early toxicity studies on Wistar rats [6]. Brantom et al. [7] provided a slightly wider LD50 range for sodium cyclamate: $12-17 \mathrm{~g} / \mathrm{kg}$. The human acceptable daily intake (ADI) was determined by the Scientific Committee on Food of sweeteners permitted in the European Union [2] according to which the ADI for sodium cyclamate is limited to 0-7 mg/ $\mathrm{kg}$ and for saccharine the ADI is limited to $0-5 \mathrm{mg} / \mathrm{kg}$. Given the widespread consumption of artificial sweeteners, many studies have been performed to establish their correlation with various metabolic diseases, oxidative stress and cancer incidence.

Much attention has been given to alterations of the lipid profile, $[8,9]$ oxidative stress parameters, [10] electrolytes, hormonal levels [11] and body weight [12]. Hematological parameters are less frequently analyzed and the results of studies are not entirely consistent, which may be due to the differences in the selected artificial sweetener and the dose or the treatment duration. The majority of reports are based on the use of aspartame, saccharine or their combination [13]. The effects of aspartame on the redox status has been extensively elaborated on rat experimental models, however there is a shortage of knowledge about the reactive oxygen species (ROS) mediated damage and subsequent changes in antioxidant levels caused by the

How to cite this article: Ibragić $S$, Fehratović $E$, Suljević $D$, Mitrašinović-Brulić M. Artificial sweeteners elicit oxidative stress in rat brain and development of microcytic anemia: Promising protective effects of vitamin C. J Res Pharm. 2021; 25(2): 117-123. 
intake of saccharine and sodium cyclamate. Thus, one of the aims of this study was to determine the catalase (CAT) activity in brain tissue homogenates. Compared with other organs, the brain is especially susceptible to oxidative stress [14] and CAT (EC 1.11.1.6) is primarily responsible for the removal of hydrogen peroxide.

Finally, ascorbic acid or vitamin $C$ was administered in combination with the artificial sweetener in order to establish its potential efficiency in attenuating the oxidative stress processes evaluated by catalase activity as well as alterations in the values of hematological parameters(blood cell count, erythrocyte indices and hemoglobin values).

\section{RESULTS}

Among the analyzed hematological parameters, the following showed a statistically significant difference between the experimental groups: $\mathrm{RBC}, \mathrm{Hb}, \mathrm{HCT}$ and MCV (Table 1). With the increase of the sweetener dose, the number of erythrocytes, hemoglobin concentration, HCT and MCV values decreased significantly. However, those values inclined significantly upon treatment with $\mathrm{H}+\mathrm{vit} \mathrm{C}$. Vitamin $\mathrm{C}$ seemed to have a beneficial role bringing the parameters close to the values observed in the control group (CG). The opposite effect was observed in the case of the leukocyte count and MCHC values that increased with the increasing sweetener dose. The $\mathrm{H}+$ vit $\mathrm{C}$ treatment again, caused a contrary finding, namely decreased WBC and MCHC values.

Figure 1 presents the obtained results describing the antioxidative activity in tissue homogenates and serum samples determined by measuring the CAT activity in three time intervals. In all time intervals, both sweetener doses lead to a decrease in CAT activity, implying a higher consumption of the enzyme during oxidative stress. When compared to the CG, this change was significant for the high dose, only. Interesting findings were observed in the group treated with $\mathrm{H}+$ vit $\mathrm{C}$. The CAT activity was higher compared to $\mathrm{H}$ and $\mathrm{L}$, reaching values that are close to the controls. This observation suggests a protective role of vitamin $\mathrm{C}$ that is potentially reducing the enzyme's activity that would be normally required to quench or neutralize the damage caused by free radicals.

\section{DISCUSSION}

Literature review revealed that the majority of animal experimental studies that aimed to evaluate the potentially harmful effects of artificial sweeteners were based on aspartame $[8,9,15]$ and that rather a moderate number of studies is oriented towards the combination of sodium cyclamate and saccharine. Both doses caused a statistically significant decrease in $\mathrm{RBC}, \mathrm{HCT}, \mathrm{Hb}$ and $\mathrm{MCV}$ values compared to the control group. This is in line with an early study conducted by Dhabar and McEwen [16] where mice were fed with saccharine. Similarly, Abdallah [17] reported that rats fed on saccharine for 30 days developed anemia as indicated by the decrease in RBC and $\mathrm{Hb}$. The same effect was also observed in aspartame treated mice for 30 days [18]. The depletion of RBC was also confirmed using aspartame alone or in combination with saccharine [19]. Opposing results were presented by Iroghama et al. [20] who recorded a significant increase in RBC caused by both aspartame and saccharine. Our results (Table 1) showed a linear reduction of RBC, HCT, Hb and MCV with the dose increase compared to controls. The statistical difference between those parameters was also evident between the low and high dose.

While the mechanism behind these changes is not fully understood, it may be attributed to the depressed erythropoesis caused by the direct action of the sweeteners on hematopoietic tissue [18]. The administration of vitamin $C$ proved to be beneficial. The supplementation with vitamin $C$ significantly increased all four parameters in comparison with the high dose. Thus, in case of $\mathrm{RBC}$ and $\mathrm{Hb}$ the content of the high dose was $4.34 \pm 0.69 \times 1012 / \mathrm{L}$ and $120.09 \pm 0.11 \mathrm{~g} / \mathrm{L}$, respectively whereas in the group exposed with the high dose and vitamin $C$ those values increased to $4.63 \pm 0.27 \times 1012 / \mathrm{L}$ of erythrocytes and $129.00 \pm 0.27$ $\mathrm{g} / \mathrm{L}$, respectively. Similar results were obtained by Abdelaziz and Ashour [13] who reported that vitamin C or E $(150 \mathrm{mg} / \mathrm{kg})$ were able to reduce the effects of saccharine intake. The brain CAT activity was measured to gain an insight into the oxidative status. Catalase is an active and first enzyme that shows alteration, following oxidative stress [21]. It is one of the components of the endogenous antioxidant that has a key role in the enzymatic defense of the cells converting reactive oxygen species into harmless products [22]. The results obtained in this study consistently showed an inverse correlation between CAT activity and the artificial sweetener dose. While both doses caused a decrease in CAT activity compared to the control group, a significant change was only evident for the high dose in all three time intervals observed. 
Table 1. Hematological parameters in the investigated groups and a statistically significant difference.

\begin{tabular}{|c|c|c|c|c|c|}
\hline Parameter & CG & $\mathbf{L}$ & $\mathbf{H}$ & $\mathrm{H}+\operatorname{vit} \mathrm{C}$ & Sig. \\
\hline $\mathrm{RBC}\left(x 10^{12} / \mathrm{L}\right)$ & $6.15 \pm 0.27$ & $5.30 \pm 0.02^{*}$ & $4.34 \pm 0.69^{*} \#$ & $4.63 \pm 0.27^{*} \# \Delta$ & $0.032^{* *}$ \\
\hline WBC (x109/L) & $4.29 \pm 0.57$ & $6.62 \pm 0.13$ & $6.97 \pm 0.55$ & $5.97 \pm 0.47$ & 0.105 \\
\hline $\mathrm{Hb}(\mathrm{g} / \mathrm{L})$ & $142.52 \pm 0.33$ & $139.69 \pm 0.02^{*}$ & $120.09 \pm 0.11^{*} \#$ & $129.00 \pm 0.27^{*} \#$ & $0.047^{* *}$ \\
\hline $\mathrm{HCT}(\mathrm{L} / \mathrm{L})$ & $0.52 \pm 0.02$ & $0.47 \pm 0.37^{*}$ & $0.28 \pm 0.21$ *\# & $0.30 \pm 0.32 * \# \Delta$ & $0.025^{* *}$ \\
\hline $\mathrm{MCV}(\mathrm{fL})$ & $84.70 \pm 0.33$ & $69.82 \pm 0.32^{*}$ & $61.51 \pm 0.34$ *\# & $64.79 \pm 0.42 * \#$ & $0.034^{* *}$ \\
\hline $\mathrm{MCH}(\mathrm{pg})$ & $17.297 \pm 0.98$ & $17.92 \pm 1.27$ & $14.92 \pm 7.43$ & $16.38 \pm 0.92$ & 0.087 \\
\hline $\mathrm{MCHC}(\mathrm{g} / \mathrm{L})$ & $405.79 \pm 45.08$ & $337.15 \pm 23.81$ & $375.36 \pm 20.05$ & $353.82 \pm 34.53$ & 0.138 \\
\hline
\end{tabular}

* Post Hoc Tukey test: vs controls, \# vs. low dose, ^ vs. high dose

**statistically significant at 0.05

CG - Control group; $\mathrm{L}$ - low dose; $\mathrm{H}$ - high dose; $\mathrm{H}+$ vit $\mathrm{C}$ - high dose and vitamin $\mathrm{C}$
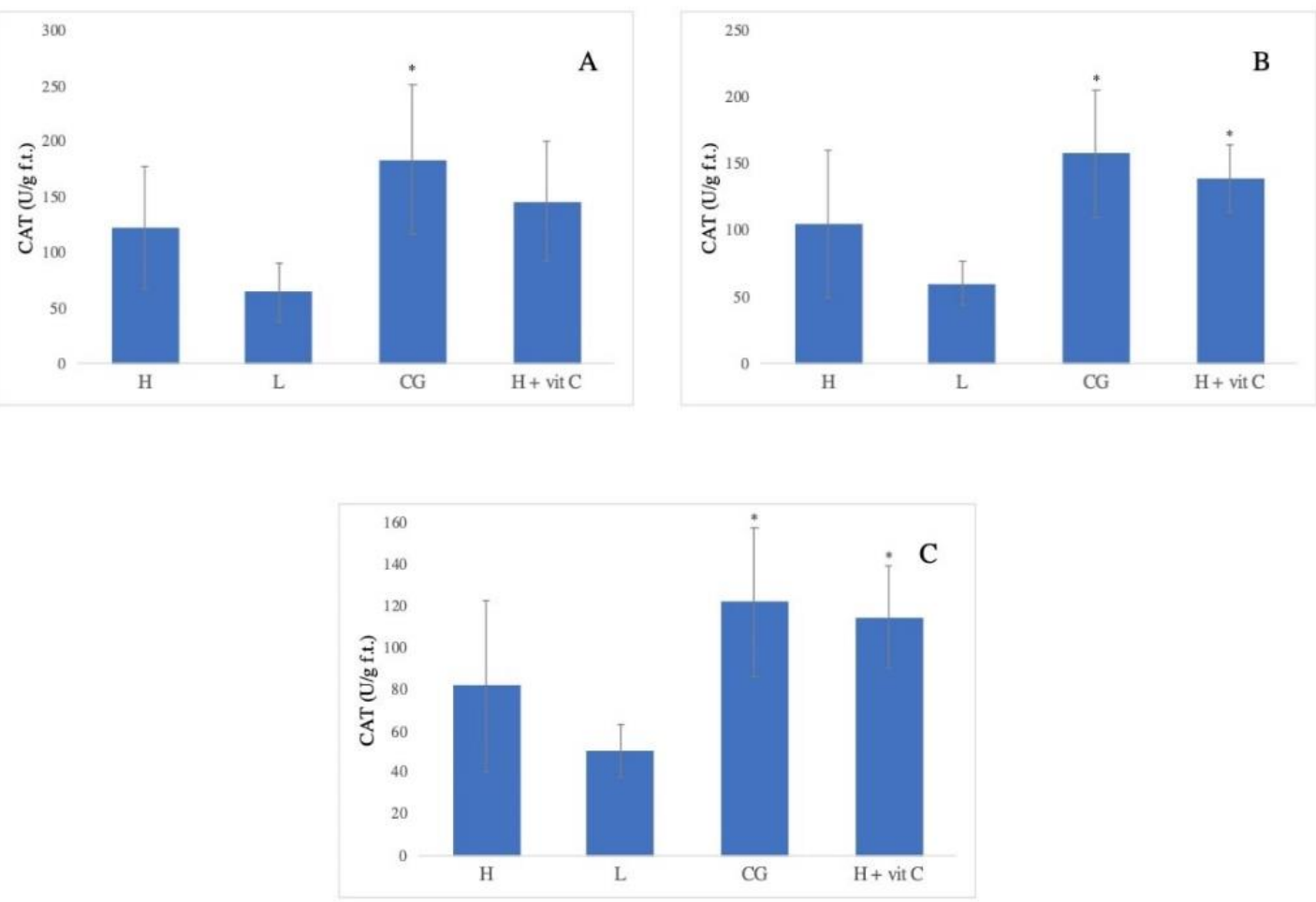

Figure 1. Catalase activity in brain tissue homogenates expressed in U/g f.t. in three-time intervals: 1-2 min (A), 2-3 $\min (\mathrm{B})$ and 1-7 $\min (\mathrm{C})$.

Similarly, Amin and Al Muzafar [8] reported a significant decline in hepatic glutathione content and CAT and superoxide dismutase (SOD) activities caused by a high dose of saccharine. Apart from the liver, the changes in activity of antioxidative enzymes induced by various artificial sweeteners have been investigated in other organs of high metabolic activity such as kidneys and brain. In a study by Adaramoye and Akanni [9] the effects of long-term administration of aspartame in three doses $(15-70 \mathrm{mg} / \mathrm{kg})$ were determined in brain and liver and it has been found that the higher doses not only reduced CAT activity but also other antioxidative parameters such as SOD (superoxide desmutase), glutathione-S-transferase and glutathione peroxidase. Our results are comparable to that considering that the CAT activity was measured by the same method and that we applied two doses in a period of 8 weeks. Contrary findings were reported by Mourad and Noor [15] who concluded that the induction of oxidative stress may depend on the treatment duration since a delayed increase in CAT activity was observed only after 6 weeks but not after 2 and 4 weeks. Carbonated soft drinks, having a high content of artificial sweeteners, are also a common subject of animal studies in terms of oxidative stress induction in brain tissue. In that regard, carbonated soft drinks were 
observed to downregulate the expression of antioxidative parameters including CAT [23] when compared with controls.

Aside from genetic mechanisms, Lebda et al. [11] went further in explaining the brain damage induced by subchronic aspartame and soft drinks treatments in rats by stating that such damage may be driven via pathways that involve energy production disruption, electrolytes and hormonal imbalance, oxidative stress and neuronal apoptosis. Collectively, the decrease of CAT activity in the current and other studies previously mentioned may be attributed to the increased consumption of the enzyme to compensate for the overproduction of free radicals caused by the artificial sweeteners intake. These results were obtained using different fish species as experimental models. Since the redox balance is of vital importance, one experimental group of the current study, treated with a high dose of artificial sweetener was also given $500 \mathrm{mg}$ vitamin C, in order to establish its effects on CAT and whether this antioxidant can attenuate the oxidative stress. Interestingly, the CAT activity of that experimental group was close to the CAT activity measured in the controls. Furthermore, the CAT activity in rats treated with the high dose of artificial sweeteners and vitamin $\mathrm{C}$ was significantly higher compared to the group treated with a high dose of artificial sweeteners only. Based on these grounds, it appears reasonable to assume that vitamin C efficiently neutralized the harmful effects of free radicals thereby decreasing the enzyme activity otherwise required to counteract the same damage. Alternatively, it may be the synergistic action of both antioxidants which led to the smaller consumption of CAT. In either case, the results prove that long-term administration of sodium cyclamate / saccharine combination significantly decreased CAT activity while vitamin C attenuated some of the oxidative damage in which case the enzyme activity was close to that in the controls.

\section{CONCLUSION}

In conclusion, this study demonstrated that a long-term treatment of Wistar rats with the combination of sodium cyclamate and saccharine induced hematological changes e.g. decreased RBC, Hb, HCT and MCV values. Hematological changes suggest the presence of microcytic anemia. Both, the low and high dose of the sweeteners suggest oxidative stress processes in the brain tissue which was reflected in the decreased values of CAT activity. Vitamin C, which was administered alternately with the high dose of sweeteners, proved to be beneficial in terms of reducing the effects of the sweeteners on the hematological status. In addition, it may be useful in ameliorating the oxidative stress. That conclusion is based on the reduced consumption of CAT compared to the group which was given the high dose sweeteners, only. A more precise conclusion might be drawn upon measuring other enzymatic and non-enzymatic antioxidants

\section{MATERIALS AND METHODS}

\subsection{Animal maintenance and ethical approval}

Male Wistar rats, Rattus norvegicus, (University of Sarajevo, Faculty of Science), weighing 200-250 g, kept on $12 \mathrm{~h} / 12 \mathrm{~h}$ light and dark cycle were used in all experiments. They were kept at controlled temperature conditions $\left(22-23^{\circ} \mathrm{C}\right)$ and fed with pelleted food (Oxbow Essentials) with water ad libitum. The experiments were conducted according to the European Communities Council Directive [24]. The Ethics Committee of the Faculty of Science, University of Sarajevo, issued the approval for this study (01/01-215-2-2020). The animals were housed and bred in the Laboratory for Biochemistry and Physiology, Faculty of Science, Sarajevo.

\subsection{Animal exposure scenarios and dosing criteria}

According to the producer's declaration, one artificial Huxol sweetener tablet (Nutrisun GmbH \& Co. KG, Germany) contains $40 \mathrm{mg}$ sodium-cyclamate and $4 \mathrm{mg}$ saccharine. Other ingredients include sodium bicarbonate, sodium citrate and lactose. Animals were randomized and assigned to four experimental groups, as presented in Table 2. Each group contained six Wistar rats. The control group was given water and food $a d$ libitum. Three experimental groups were exposed with $20 \mathrm{~mL}$ of a low dose of sweetener $(\mathrm{L} ; 15.4 \mathrm{mg} / \mathrm{mL})$, high dose of sweetener $(\mathrm{H} ; 22 \mathrm{mg} / \mathrm{mL})$ and high dose and vitamin $\mathrm{C}$ alternately $(\mathrm{H}+$ vit $\mathrm{C} ; 22 \mathrm{mg} / \mathrm{mL}+25$ $\mathrm{mg} / \mathrm{mL}$ ), every other day. Using a dose of sweetener and vitamin C (Acidum ascorbicum Plivit C, Pliva, Croatia) as tablets were previously dissolved in $20 \mathrm{~mL}$ of water. The doses were chosen upon literature review $[8,25]$. The experimental period lasted 8 weeks. 
Table 2. Treatment regime of the experimental groups.

\begin{tabular}{lllcc}
\hline Group & Label & Treatment & $\begin{array}{l}\text { Sodium } \\
\text { cyclamate/dose }\end{array}$ & Saccharine/ dose \\
\hline Control group & CG & Food and water ad libitum & -- & -- \\
Low dose & $\mathrm{L}$ & $\begin{array}{l}15.4 \mathrm{mg} / \mathrm{mL} \text { sweetener }(7 \text { tablets in } 20 \\
\mathrm{mL} \text { water })\end{array}$ & $14 \mathrm{mg} / \mathrm{mL}$ & $1.4 \mathrm{mg} / \mathrm{mL}$ \\
High dose & $\mathrm{H}$ & $\begin{array}{l}22 \mathrm{mg} / \mathrm{mL} \text { sweetener }(10 \text { tablets in } 20 \\
\mathrm{mL} \text { water })\end{array}$ & $20 \mathrm{mg} / \mathrm{mL}$ & $2 \mathrm{mg} / \mathrm{mL}$ \\
$\begin{array}{l}\text { High dose }+ \\
\text { vitamin } \mathrm{C})\end{array}$ & $\mathrm{H}+$ vit C & $\begin{array}{l}22 \mathrm{mg} / \mathrm{mL} \text { sweetener }+25 \mathrm{mg} / \mathrm{mL} \\
\text { vitamin C }(10 \text { tablets in } 20 \mathrm{~mL} \text { water } \\
\text { and } 500 \mathrm{mg} \text { vit } \mathrm{C} \text { in } 20 \mathrm{~mL} \text { water })\end{array}$ & $20 \mathrm{mg} / \mathrm{mL}$ & $2 \mathrm{mg} / \mathrm{mL}$ \\
\hline
\end{tabular}

\subsection{Blood sampling and assessment of hematological indices}

At the end of experimental period ( $24 \mathrm{~h}$ after the last dose), the animals were anesthetized, followed by euthanasia as described by Suljevic et al. [26]. Blood samples were collected via the cardiac puncture with the small gauge needle (21G, Semikem, Bosnia and Herzegovina). Blood without anticoagulants was used for the analysis of hematological parameters. The following hematological parameters were analyzed: erythrocytes count (RBC), leukocyte count (WBC); hemoglobin concentration ( $\mathrm{Hb})$; hematocrit (HCT) and erythrocytes indices (MCV - mean cell volume, $\mathrm{MCH}$ - mean corpuscular hemoglobin and $\mathrm{MCHC}$ - mean corpuscular hemoglobin concentration).

RBC was determined using the Neubauer hemocytometer (Merck, Germany). To obtain the erythrocyte count, the whole blood was diluted (1: 100) in the isotonic Hayem solution (Semikem, Bosnia and Herzegovina). The total erythrocyte count per litre of blood was determined by multiplying the number of counted erythrocytes $x$ dilution (100) $x$ depth of the chamber (10) $x$ square surface (5) $\times 10^{12}$.

WBC was determined by using of the Bürker-Türk hemocytometer (Merck, Germany). For analysis of the leukocyte count, blood was diluted (1:500) in the Türk reagent (Semikem, Bosnia and Herzegovina). The RBC and WBC were determined by counting cells in a hemocytometer and using the Olympus BX41 Microscope with Binocular Head (USA). The total lymphocyte count per litre of blood was determined by multiplying the number of counted lymphocyte $x$ dilution (500) $x$ depth of the chamber (10) $x$ square surface (4) $\times 10^{9}$.

To perform the hematocrit test (HCT), blood was drawn using the heparinized microhematocrit capillary tubes which were then placed into a centrifuge (16000 rpm, $10 \mathrm{~min})$. The hematocrit is calculated as the simple ratio of plasma to blood cells, which is measured by a graphical scale as per manufacturer's instructions (Hettich Haematokrit 24, Germany).

Hemoglobin concentration was determined spectrophotometrically by Drabkin's method [27] using the SPECTRONIC GENESYSTM20 spectrophotometer. Oxidation of hemoglobin in solution finally forms cyanmethemoglobin, with the maximum absorption at $546 \mathrm{~nm}$.

$\mathrm{MCV}$ was calculated by dividing HCT by the total number of erythrocytes; $\mathrm{MCH}$ was calculated by dividing the hemoglobin concentration by $\mathrm{RBC}$, and $\mathrm{MCHC}$ was determined by dividing the hemoglobin concentration by the hematocrit value.

\subsection{Brain isolation, tissues processing and catalase activity assay}

After euthanasia of the animals, brain isolation was performed. The brain was rapidly excised from each animal, trimmed of connecting tissue, washed free of blood with $0.9 \% \mathrm{NaCl}$ solution and distilled water. The brain was homogenized with $0.1 \mathrm{M}$ phosphate buffer saline at $\mathrm{pH} 7.4$, to give a final concentration of $10 \% \mathrm{w} / \mathrm{v}$ for the biochemical assays. The homogenates were centrifuged at $10000 \mathrm{rpm}$ for $10 \mathrm{~min}$ at $4{ }^{\circ} \mathrm{C}$ and the supernatants used for the determination of CAT (catalase) activity. Catalase activity was determined according to Aebi [28].

The decomposition of $\mathrm{H}_{2} \mathrm{O}_{2}$ can be followed directly by the decrease in absorbance at $240 \mathrm{~nm}$. Briefly, $2.0 \mathrm{~mL}$ of diluted tissue homogenate was incubated with $1 \mathrm{~mL}$ of $\mathrm{H}_{2} \mathrm{O}_{2}(30 \mathrm{mM})$. The control contained $2 \mathrm{~mL}$ phosphate buffered saline (PBS; $\mathrm{pH}=7.4)$ and $1 \mathrm{~mL} \mathrm{H}_{2} \mathrm{O}_{2}(30 \mathrm{mM})$ - a solution that shows the absorbance $\mathrm{A}=$ 0.5 . The difference in absorbance $\left(\Delta_{240}\right)$ per time unit is a measure of the catalase activity. The $\Delta_{240}$ was recorded 
for 7 minutes and the CAT activity calculated for three time points: $1-2 \mathrm{~min}, 2-3 \mathrm{~min}$ and $1-7 \mathrm{~min}$ to account for the consistency of the obtained results. One unit of activity was defined as the amount of enzyme catalyzing the decomposition of $1 \mu \mathrm{mol} \mathrm{H} \mathrm{H}_{2}$ per min, calculated from the extinction coefficient $\left(36 \mathrm{M}^{-1} \mathrm{~cm}^{-1}\right)$ for $\mathrm{H}_{2} \mathrm{O}_{2}$ at $240 \mathrm{~nm}$. All measurements were per formed in triplicate and results are expressed as mean values \pm SD.

\subsection{Statistical Analysis}

The generated data were analyzed using the Statistical package for social sciences (SPSS ver. 10). The hematological parameters and CAT activity were interpreted upon performing the ANOVA and consecutively the Post Hoc Tukey test. The statistical significance was set at $\mathrm{P}<0.05$.

Acknowledgements: Authors would like to thank Dr. Andi Alijagic for critically reading the manuscript.

Author contributions: Concept - S.I., M.MB.; Design - S.I, E.F., M.MB.; Supervision - S.I., D.S.; Resources - S.I., M.MB.; Materials - S.I., M.MB.; Data Collection and/or Processing - E.F., M.MB.; Analysis and/or Interpretation - S.I., E.F., D.S., M.MB.; Literature Search - S.I., E.F., D.S.; Writing - S.I., D.S.; Critical Reviews - S.I., E.F., D.S., M.MB.

Conflict of interest statement: All authors declare no conflict of interest.

Ethics committee approval: The Ethics Committee of the Faculty of Science, University of Sarajevo, issued the approval for this study (01/01-215-2-2020).

\section{REFERENCES}

[1] World Health Organization, 2015. WHO calls on countries to reduce sugars intake among adults and children. Press release. https://www.who.int/mediacentre/news/releases/2015/sugar-guideline/en/ (accessed March 2019).

[2] Mortensen A. Sweeteners permitted in the European Union: safety aspects. Food Nutr Res. 2006;50(3):104-116. [CrossRef]

[3] Bopp BA, Sonders RC, Kesterson JW, Renwick AG. Toxicological aspects of cyclamate and cyclohexylamine. Critical Rev Toxicol. 1986; 16(3): 213-306. [CrossRef]

[4] Renwick AG, Thompson JP, O'shaughnessy M, Walter EJ. The metabolism of cyclamate to cyclohexylamine in humans during long-term administration. Toxicol Appl Pharmacol. 2004; 196(3): 367-380. [CrossRef]

[5] Chattopadhyay S, Raychaudhuri U, Chakraborty R. Artificial sweeteners-a review. J Food Sci Technol. 2014; 51(4): 611-621.[CrossRef]

[6] Taylor JD, Richards RK, Wiegand RG, Weinberg MS. Toxicological studies with sodium cyclamate and saccharin. Food Cosmetics Toxicol. 1968; 6(3): 313-327. [CrossRef]

[7] Brantom PG, Gaunt IF, Grasso P. Long-term toxicity of sodium cyclamate in mice. Food Cosmetics Toxicol. 1973; 11(4): 735-746. [CrossRef]

[8] Amin KA, AlMuzafar HM. Alterations in lipid profile, oxidative stress and hepatic function in rat fed with saccharine and methyl-salicylates. Int J Clin Exp Med. 2015; 6133-6144.

[9] Adaramoye OA, Akanni OO. Effects of long-term administration of aspartame on biochemical indices, lipid profile and redox status of cellular system of male rats. J Basic Clin Physiol Pharmacol. 2016; 27(1): 29-37. [CrossRef]

[10] Ashok I, Poornima PS, Wankhar D, Ravindran R, Sheeladevi R. Oxidative stress evoked damages on rat sperm and attenuated antioxidant status on consumption of aspartame. Int J Impot Res. 2017; 29(4): 164-170. [CrossRef]

[11] Lebda MA, Sadek KM, El-Sayed YS. Aspartame and soft drink-mediated neurotoxicity in rats: implication of oxidative stress, apoptotic signaling pathways, electrolytes and hormonal levels. Metab Brain Dis. 2017; 32(5): 16391647.[CrossRef]

[12] Polyák É, Gombos K, Hajnal B, Bonyár-Müller K, Szabó S, Gubicskó-Kisbenedek A, Marton K, Ember I. Effects of artificial sweeteners on body weight, food and drink intake. Acta Physiol Hung. 2010; 97(4): 401-407. [CrossRef]

[13] Abdelaziz I, Ashour AERA. Effect of saccharin on albino rats' blood indices and the therapeutic action of vitamins C and E. Hum Exp Toxicol. 2011; 30(2): 129-137. [CrossRef]

[14] Butterfield DA, Stadtman ER. Protein oxidation processes in aging brain. In: Advances in cell aging and grontology, Elsevier. 1997; 2: 161-191. [CrossRef]

[15] Mourad IM, Noor NA. Aspartame (a widely used artificial sweetener) and oxidative stress in the rat cerebral cortex. Int J Pharmd Biomed Sci. 2011; 2(1): 4-10. 
[16] Dhabhar FS, McEwen BS. Biodirectional effects of stress and glucocorticoid hormones on immune function: Possible explanations for paradoxical observations, In: Ader, R., Felten, D.L. and Cohen, N. (Eds.). Psychoneuroimmunology. San Diego, CA: Academic Press. 2001: 301-338.

[17] Abdallah IZ. Physiological changes induced by long term administration of saccharin compared with aspartame to male albino rats. Egyptian J Hosp Med. 2002; 8(1): 70-81. [CrossRef]

[18] Naik AQ, Shrivastava VK. Effects of short-term consumption of aspartame on some biochemical and hematological parameters in female swiss albino mice. Int J Zoo Res. 2019; 15: :21-27. [CrossRef]

[19] Abu-Taweel GM. Effects of curcumin on the social behavior, blood composition, reproductive hormones in plasma and brain acetylcholinesterase in cadmium intoxicated mice. Saudi J Biol Sci. 2016; 23(2): 219-228. [CrossRef]

[20] Iroghama AA, Awo OM, Iwamo O. Haematological and haemostatic effects of aspartame and saccharin in albino Wistar rats. J Sci Technol. 2017; 3: 14-2.

[21] Jin Y, Zhang X, Shu L, Chen L, Sun L, Qian H, Liu W, Fu Z. Oxidative stress response and gene expression with atrazine exposure in adult female zebrafish (Danio rerio). Chemosphere. 2010; 78(7): 846-852. [CrossRef]

[22] Weydert CJ, Cullen JJ. Measurement of superoxide dismutase, catalase and glutathione peroxidase in cultured cells and tissue. Nature protocols. 2010; 5(1): 51-66. [CrossRef]

[23] ElTerras A, Soliman MM, Alkhedaide A, Attia HF, Alharthy A, Banaja AE. Carbonated soft drinks induce oxidative stress and alter the expression of certain genes in the brains of Wistar rats. Mol Med Reports. 2016; 13(4): 3147-3154. [CrossRef]

[24] Directive C. 86/609/EEC. On the approximation of laws, regulations and administrative provisions of the Member States regarding the protection of animals used for experimental and other scientific purposes. Official J Europ Comm. 1986; 29: 358.

[25] Rogers PJ, Hogenkamp PS, De Graaf C, Higgs S, Lluch A, Ness AR, Penfold C, Perry R, Putz P, Yeomans MR, Mela DJ. Does low-energy sweetener consumption affect energy intake and body weight? A systematic review, including meta-analyses, of the evidence from human and animal studies. Int J Obes. 2016; 40(3): 381-394. [CrossRef]

[26] Suljevic D, Hamzic A, Focak M, Zahirovic A, Alijagic A. Morphological and cytochemical characterization of the sternal leukopoietic cell lineages in wistar rat. Int J Fauna Biol Stud. 2017; 4(5): 99-103.

[27] Balasubramaniam P, Malathi A. Comparative study of hemoglobin estimated by Drabkin's and Sahli'smethods. J Postgrad Med. 1992; 38: 8-9.

[28] Aebi H. Catalase in vitro. In: Methods in enzymology. Elsevier, Academic Press.1984; 105: 121-126. [CrossRef]

This is an open access article which is publicly available on our journal's website under Institutional Repository at http://dspace.marmara.edu.tr. 